\title{
The Murine Retinoblastoma Homolog Maps to Chromosome 14 near Es-10
}

\author{
James C. Stone, ${ }^{\star}$ Jefrerey L. Crosby, ${ }^{\star} †$ Christine A. Kozak, $\ddagger$ Andrea R. Schievella, $\S$ \\ Rene Bernards, $\S$ and Joseph H. Nadeau* \\ *The Jackson Laboratory, Bar Harbor, Maine 04609; †Biochemistry Department, University of Maine, Orono, Maine 04469; \\ $\ddagger$ Laboratory of Molecular Biology, National Institutes of Allergy and Infectious Diseases, Bethesda, Maryland 20892; and §The \\ Cancer Research Center of the Massachusetts General Hospital and Harvard Medical School, Charlestown, Massachusetts 02129
}

Received December 7, 1988; revised February 17, 1989

Restriction fragment length variants have been exploited to map genetically $R b-1$, the murine homolog of the human retinoblastoma gene. $R b-1$ localized to mouse chromosome 14 on the basis of results from analysis of somatic cell hybrids. In an interspecific backcross involving Mus spretus, $R b-1$ and the murine homolog of the human esterase D gene (ESD), which we refer to here as $E s d$, were inseparable. Furthermore, the strain distribution patterns of $R b-I$ and $E s$ 10 are the same in 31 of 32 recombinant inbred strains. Close linkage of the chromosome 14 morphological marker hairless $(h r)$ to $R b-I$ is also implied. These results localize $R b-1$ on the mouse linkage map and provide close genetic markers to follow $R b-1$ in somatic as well as in germline genetic experiments. Additionally, the results suggest that Es-1O is the murine homolog of ESD and provide further evidence for linkage conservation during mammalian evolution. () 1989 Academic Press, Inc.

\section{INTRODUCTION}

The human retinoblastoma gene is the prototypic recessive cancer gene; loss of $\mathrm{RB} 1$ function contributes to neoplastic development. The existence of the gene was originally postulated to account for epidemiological data that suggested that rare sporadic retinoblastomas occur at a frequency indicative of two mutational events, while the disease arises with a high frequency in the familial form because affected individuals inherit only one functional copy of RB1 (Knudson, 1971). Several recessive oncogenes, also referred to as antioncogenes and tumor suppressor genes, have now been postulated and it seems that understanding the normal function of this type of gene will prove to be fundamental to understanding oncogenesis (Klein, 1987).

Cytogenetic and molecular mapping methods demonstrated the existence of $R B 1$ on human chromosome
13 near esterase D (Sparkes et al., 1980, 1983; Cavenee et al., 1983). $R B 1$ has been isolated as molecular clones in a number of laboratories and the veracity of these clones has been established by the demonstration that the corresponding genomic sequence is disrupted in a large number of retinoblastomas as well as in some sarcomas (Friend et al., 1986, 1987; Lee et al., 1987a; Fung et al., 1987; Goddard et al., 1988; Dunn et al., 1988). The isolation of molecular probes has additionally led to the identification of an $R B 1$-encoded nuclear phosphoprotein that presumably performs the normal growth-regulating function of this gene (Lee et al., 1987b; Friend et al., 1987).

Recessive oncogenes do not lend themselves to the type of structure-function studies that have been so useful in dissecting the transforming proteins of dominant oncogenes. Rather, it may be more appropriate to use classical genetic methods that endeavor to study gene function using germline mutations. The ancestral retinoblastoma sequence cannot be traced to the lower eukaryotes that permit facile genetic analysis. On the basis of these considerations, we have undertaken the formal genetic analysis of the murine retinoblastoma gene, $R b-1$.

In this paper we present data that localize $R b-1$ on the mouse linkage map with respect to well-characterized markers.

\section{MATERIALS AND METHODS}

The plasmid pMRB102, containing a 4.5-kb cDNA, was isolated from a library constructed from a BALB/ c pre-B-cell line using a fragment of the human $R B 1$ cDNA as a hybridization probe (Bernards et al., 1989). The pMRB102 insert contains nearly all the coding information of the murine retinoblastoma gene, as ascertained by comparing the structure of pMRB102 with that of subsequently isolated cDNA clones and taking into account the apparent molecular mass of the pro- 
tein product of the mouse gene. The pMRB102 insert lacks about 30 codons at the extreme $5^{\prime}$ end and also lacks an extremely GC-rich $5^{\prime}$ noncoding region that may contribute to spurious hybridization signals. In the studies presented here, the $E c o$ RI fragment containing the entire insert was purified before labeling by the random primer method (Feinberg and Vogelstein, 1983). For typing the murine homolog of ESD, the insert of pESD14.1.1 (Squire et al., 1986) was used.

The use of hamster-mouse somatic cell hybrids and DNA blot methods for chromosomal assignment of mouse sequences has been described previously (Hoggan et al., 1988). Liver, brain, and spleen were used as a source of genomic DNAs in the backcross and recombinant inbred strain mapping experiments. DNA was extracted from tail material in the experiments involving hairless animals. Restriction enzyme digestions were carried out overnight under conditions recommended by the suppliers. Blot transfer to nylon membranes (GeneScreen Plus, Dupont) and hybridization were performed as recommended by the suppliers.

Typing of $N p-1$ and $E s-10$ was accomplished as described previously (Womack, 1977) using kidney homogenates as a source of nucleoside phosphorylase and blood obtained by retro-orbital bleeding for esterase-10.

\section{RESULTS}

Localization of the Murine Retinoblastoma Gene Homolog to Mouse Chromosome 14

To test the hypothesis that $R b-1$ would be syntenic to $E s-10$, the presumed homolog of $E S D$ on mouse chromosome 14, we made use of a panel of well-characterized mouse-hamster somatic cell hybrids. DNA from these hybrids was cleaved with BamHI. After resolution on agarose gels and transfer to a hybridization filter, the DNA on the filter was probed with the pMRB102 probe. Mouse and Chinese hamster DNAs differ substantially with respect to their blot patterns, with at least two major mouse-specific bands migrating distinctly from hamster fragments (Fig. 1). The presence in the hybrids of all the mouse-specific fragments, which we refer to here as $R b-1$, correlates well with the presence of chromosome 14, but not with any other chromosome in the panel of 17 hybrids (Table 1). The one discordant cell hybrid, HM71, was classified as "low positive" for chromosome 14 , with less than $15 \%$ of hybrid cells showing this mouse chromosome. Low levels of $E s-10$ expression can be detected in this hybrid, but the $R b-1$ sequence was not detected in these studies. We conclude that $R b-1$ is on chromosome 14 .

\section{Linkage of Rb-1 and the Murine Homolog of ESD}

An interspecific cross was used to evaluate linkage of $R b-1$ and the murine homolog of $E S D$, which we refer to here as Esd. To identify appropriate restriction fragment variants that could be used in linkage tests, C57BL/6J-Tr $R e /++$ and Mus spretus DNAs were digested separately with 11 different restriction enzymes and probed as described above with the pMRB102 insert. Similarly, these DNAs were digested separately with 10 different restriction enzymes followed by probing with the insert from pESD14.1.1. Species-specific

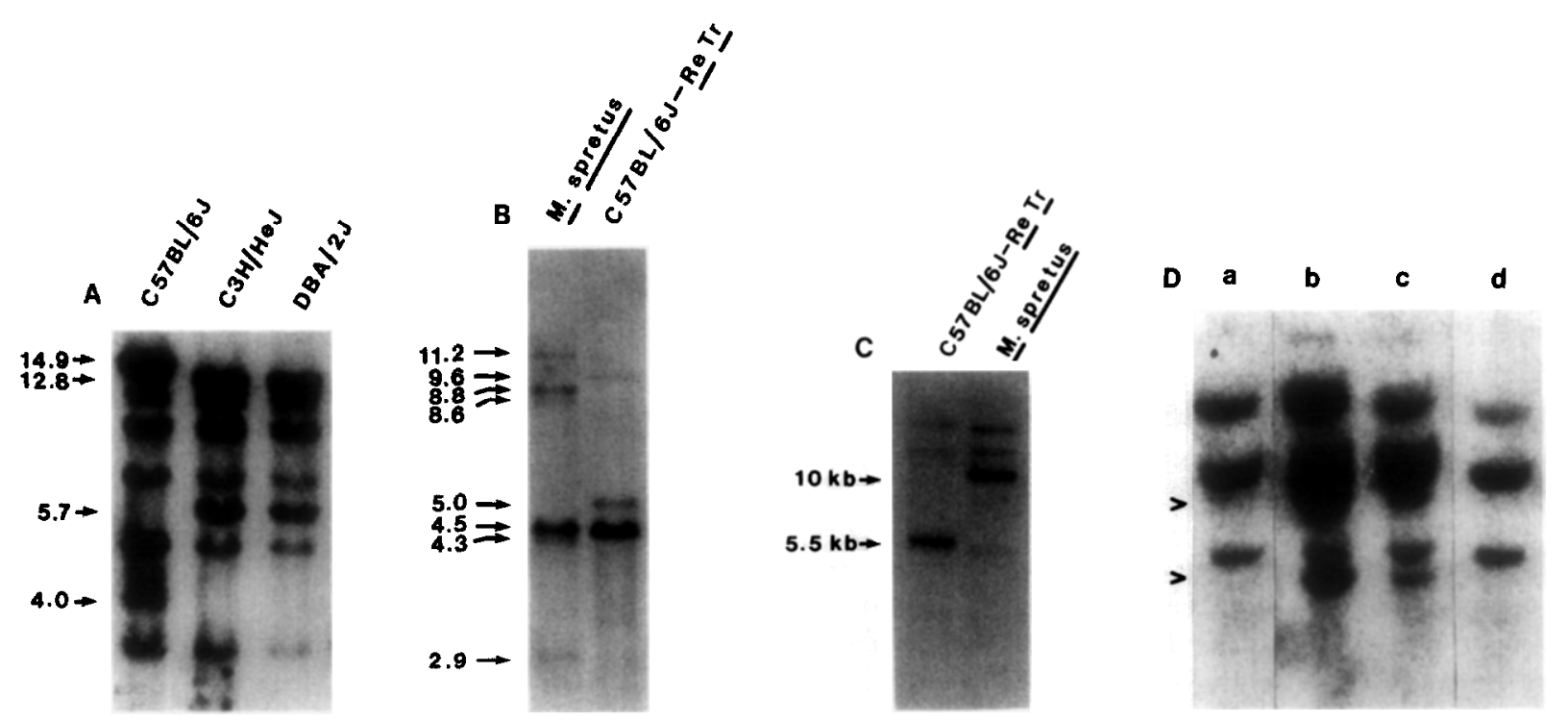

FIG. 1. Restriction fragment patterns used to map $R b-1$ and $E$ 'sd. (A) DNAs from the recombinant inbred progenitor strains were digested with $E c o R I$ and probed with pMRB102 insert. (B) $M$. spretus and C57BL/6J-Re Tr DNAs cut with BamHI and probed with ESD are compared. (C) DNAs from C57BL/6J-Re $T r$ and $M$. spretus digested with Xbal were probed with pMRB102 insert. (D) Representative somatic panel data. DNAs digested with BamHI were probed with pMRB102 insert. (a) Progenitor hamster DNA. (b) Progenitor mouse DNA. (c) Representative hybrid containing Rb-1. (d) Representative hybrid not containing $R b-1$. 


\section{TABLE 1}

Correlation between $R b-1$ and Mouse Chromosomes in Mouse-Hamster Hybrids

\begin{tabular}{|c|c|c|c|c|c|}
\hline \multirow{2}{*}{$\begin{array}{c}\text { Mouse } \\
\text { chromosome }\end{array}$} & \multicolumn{4}{|c|}{$\begin{array}{l}\text { No. hybrid clones }(R b-1) / \\
\text { chromosome retention }\end{array}$} & \multirow{2}{*}{$\begin{array}{c}\% \\
\text { Discordance }\end{array}$} \\
\hline & $+/+$ & $-1-$ & $+1-$ & $-1+$ & \\
\hline 1 & 1 & 4 & 2 & 8 & 66.7 \\
\hline 2 & 3 & 4 & 1 & 9 & 58.8 \\
\hline 3 & 2 & 5 & 0 & 8 & 53.3 \\
\hline 4 & 2 & 10 & 2 & 3 & 29.4 \\
\hline 5 & 0 & 8 & 3 & 3 & 40.0 \\
\hline 6 & 3 & 5 & 1 & 8 & 52.9 \\
\hline 7 & 4 & 5 & 0 & 8 & 47.1 \\
\hline 8 & 3 & 7 & 1 & 6 & 41.2 \\
\hline 9 & 3 & 8 & 1 & 4 & 31.2 \\
\hline 10 & 0 & 13 & 4 & 0 & 23.5 \\
\hline 11 & 0 & 12 & 4 & 0 & 25.0 \\
\hline 12 & 4 & 4 & 0 & 9 & 52.9 \\
\hline 13 & 3 & 5 & 0 & 5 & 38.5 \\
\hline 14 & 4 & 12 & 0 & 1 & 5.9 \\
\hline 15 & 3 & 1 & 0 & 11 & 73.3 \\
\hline 16 & 1 & 4 & 2 & 4 & 54.5 \\
\hline 17 & 4 & 4 & 0 & 9 & 52.9 \\
\hline 18 & 1 & 5 & 2 & 7 & 60.0 \\
\hline 19 & 2 & 7 & 2 & 6 & 47.1 \\
\hline 20 & 2 & 6 & 1 & 7 & 50.0 \\
\hline
\end{tabular}

restriction pattern differences were distinguishable for these two genes using virtually any restriction enzyme (Fig. 1).

C57BL/6J-TrJRe/++ females were crossed to $M$. spretus males, and $\mathrm{F}_{1}$ hybrid females were backcrossed to C57BL/6J males. Genomic DNAs were used for typing $R b-1$ and $E s d$. $R b-1$ was typed using $P v u I I-$ and $X b a I$-digested DNAs in two separate experiments, with identical results. Esd was typed with BamHI-digested DNAs. No recombinants between $R b-1$ and $E s d$ were found in the 87 backcross progeny. The upper $95 \%$ confidence limit on this recombination frequency is 0.034 .

We were concerned that the apparent tight linkage between these two DNA markers in an interspecific cross might reflect a structural heterology in this region of chromosome 14 that suppressed recovery of recombinants, rather than indicating a physical proximity of the two genes on the chromosome. Accordingly, 64 of the 87 backcross animals were also typed for the proximal chromosome 14 marker $N p-1$, using isozyme analysis of kidney samples. The recombination frequency between $N p-1$ and $R b-1$ (or $E s d$ ) was 0.203 \pm 0.051 (Table 2). The published recombination frequency for the interval between $N p-1$ and $E s-10$ is 0.097 \pm 0.091 using conventional mouse strains (Womack et al., 1977). Thus, the interspecific cross used here exhibited a relatively high recombination frequency in this region of chromosome 14, assuming $E s-10$ and $E s d$ are the same.

\section{Linkage of Rb-1 to Es-10}

To localize $R b-1$ more precisely on chromosome 14 , to measure the recombination frequency between $R b$ 1 and $E s-10$, and to evaluate the hypothesis that $E s$ 10 and $E s d$ are equivalent, we next used the recombinant inbred (RI) method of gene mapping. Inbred strain C57BL/6J is homozygous for the $E s-10^{a}$ allele, while $\mathrm{DBA} / 2 \mathrm{~J}$ and $\mathrm{C} 3 \mathrm{H} / \mathrm{HeJ}$ bear the $E s-10^{b}$ allele. Thus, the BXD and BXH series of RI lines (derived from intercrossing $\mathrm{C} 57 \mathrm{BL} / 6 \mathrm{~J}$ with either DBA2/J or $\mathrm{C} 3 \mathrm{H} / \mathrm{HeJ}$, respectively, followed by extensive inbreeding) are informative for this locus.

We subjected DNAs from these strains separately to digestion with 10 different restrictions enzymes. The restriction patterns obtained with the enzymes $E c o R I$, $B g l I I$, and $T a q I$ were different when patterns from C57BL/6J animals were compared with patterns from either $\mathrm{DBA} / 2 \mathrm{~J}$ or $\mathrm{C} 3 \mathrm{H} / \mathrm{HeJ}$; the latter two strains are identical by restriction analysis. The restriction pattern found in C57BL/6J is referred to as the $R b-1^{b}$ allele while $R b-I^{d}$ refers to the pattern found in DBA/2J and $\mathrm{C} 3 \mathrm{H} / \mathrm{HeJ}$.

Using the $R b-1$ types defined by $E c o R I$ digestion (Fig. 1), we classified DNAs from $22 \mathrm{BXD}$ RI and $12 \mathrm{BXH}$ RI strains using the pMRB102 probe. The strain distribution patterns for $R b-1$ were compared to the patterns of previously mapped chromosome 14 genes, including $E s-10$ (Table 3). One recombinant between $R b$ 1 and $E s-10$ was detected in the BXH strains and none in the BXD strains, indicating very close linkage for these two genes. Furthermore, the results indicate that $E s-10$ and $E s d$ must be very closely linked and may be identical. To guard against possible misclassifications, DNAs from two different animals from the exceptional strain, BXH2, were analyzed and the $E s-10$ genotype

TABLE 2

Recombination between $N p-1, R b-1$, and $E s d$ in the Backcross (C57BL/6J $\times M$. spretus) $F_{1}$ Female $\times($ C57BL/6J) Male

\begin{tabular}{|c|c|c|c|c|}
\hline \multicolumn{4}{|c|}{ Allelic combination } & \multirow{2}{*}{$\begin{array}{l}\text { Number } \\
\text { observed }\end{array}$} \\
\hline$N p-1$ & & $R b-1$ & Esd & \\
\hline$a b$ & & BS & BS & 21 \\
\hline$a$ & & $\mathbf{B}$ & B & 30 \\
\hline$a b$ & $x$ & B & B & 9 \\
\hline$a$ & $x$ & BS & BS & 4 \\
\hline \multicolumn{4}{|l|}{ Total } & 64 \\
\hline
\end{tabular}

Note. An $x$ indicates the location of a crossover. S and B are used as generic symbols for alleles of $R b-1$ and $E s d$ in $M$. spretus and C57BL/6J, respectively. 
TABLE 3

Inheritance of $R b-1$ and Other Chromosome 14 Genes in BXD and BXH Recombinant Inbred Strains of Mice

\begin{tabular}{|c|c|c|c|c|c|c|c|c|c|c|c|c|c|c|c|c|c|c|c|c|c|c|}
\hline \multirow[b]{2}{*}{ Gene } & \multicolumn{22}{|c|}{ BXD strain } \\
\hline & 1 & 2 & 5 & 6 & 8 & 9 & 11 & 12 & 13 & 14 & 15 & 16 & 18 & 19 & 20 & 22 & 23 & 24 & 25 & 27 & 28 & 29 \\
\hline$N p-2$ & $\mathbf{B}$ & D & B & D & $\mathrm{D}$ & $\mathrm{D}$ & D & D & B & D & $\mathrm{D}$ & D & D & D & $\mathbf{B}$ & B & B & B & B & $\mathbf{B}$ & B & D \\
\hline Tera & $\mathbf{B}$ & $\mathbf{D}$ & B & $\mathbf{D}$ & $\mathrm{D}$ & $\mathrm{D}$ & $\mathrm{D}$ & $\mathrm{D}$ & $\mathrm{B}$ & $\mathrm{D}$ & $\mathrm{D}$ & $\mathrm{D}$ & D & $\mathrm{D}$ & $\mathbf{B}$ & B & B & $\mathbf{B}$ & B & $\mathbf{B}$ & B & D \\
\hline$R i b-1$ & B & $\mathrm{D}$ & B & $\mathrm{D}$ & D & $\mathrm{D}$ & $\mathrm{D}$ & $\mathrm{D}$ & B & $\mathrm{D}$ & $\mathrm{D}$ & D & $\mathrm{D}$ & $\bar{D}$ & B & $\mathrm{B}$ & B & $\mathbf{B}$ & $\mathrm{B}$ & $\mathbf{B}$ & B & D \\
\hline & & & & & & & & $x$ & & & & $x$ & $x$ & & & & & & $x$ & & & \\
\hline$R b-1$ & $\mathbf{B}$ & D & B & D & D & D & $\mathrm{D}$ & $\mathbf{B}$ & B & D & $\mathbf{D}$ & B & $\mathbf{B}$ & D & B & B & B & $\mathbf{B}$ & D & $\mathbf{B}$ & B & D \\
\hline \multirow[t]{2}{*}{$E s-10$} & B & $\mathrm{D}$ & B & $\mathrm{D}$ & D & $\mathrm{D}$ & $\mathrm{D}$ & B & B & D & $\mathrm{D}$ & B & B & $\mathrm{D}$ & B & $\mathrm{B}$ & B & B & $\mathrm{D}$ & B & B & D \\
\hline & \multicolumn{22}{|c|}{ BXH strain } \\
\hline Gene & & 2 & & 3 & & 4 & & 6 & 7 & & 8 & & 9 & & 10 & & & 12 & & 14 & & 19 \\
\hline$R i b-1$ & & $\mathrm{H}$ & & B & & $\mathbf{H}$ & & B & B & & $\mathbf{H}$ & & B & & B & & & B & & $\mathbf{H}$ & & $\mathrm{H}$ \\
\hline$R b-1$ & & $\mathbf{H}$ & & $\mathbf{B}$ & & $\mathbf{H}$ & & B & $\mathbf{B}$ & & $\mathrm{H}$ & & B & & B & & & B & & $\mathbf{H}$ & & $\mathrm{H}$ \\
\hline Es-10 & & $\begin{array}{l}x \\
\text { B }\end{array}$ & & $\mathbf{B}$ & & $\mathrm{H}$ & & B & $\mathbf{B}$ & & $\mathbf{H}$ & & B & & $\mathbf{B}$ & & & B & & $\mathbf{H}$ & & $\mathrm{H}$ \\
\hline
\end{tabular}

Note. Progenitors of the BXD and BXH recombinant inbred strains are $\mathrm{C} 57 \mathrm{BL} / 6 \mathrm{~J}$ and DBA/2J and $\mathrm{C} 57 \mathrm{BL} / 6 \mathrm{~J}$ and $\mathrm{C} 3 \mathrm{H} / \mathrm{HeJ}$, respectively. $\mathrm{B}, \mathrm{D}$, and $\mathrm{H}$ are used as generic terms for alleles inherited from $\mathrm{C} 57 \mathrm{BL} / 6 \mathrm{~J}, \mathrm{DBA} / 2 \mathrm{~J}$, and $\mathrm{C} 3 \mathrm{H} / \mathrm{HeJ}$, respectively. An $x$ denotes intervals where crossingover resulted in recombination. Sources for data are the following: $E s-10$ (esterase-10 (3)), $N p$-2 (nucleoside phosphorylase-2 (5)), Rib$I$ (pancreatic ribonuclease-1 (7)), and Tcra (T-cell receptor, alpha-chain (5)). $N p \sim 2$ controls the electrophoretic mobility of an erythrocytespecific form of nucleaside phosphorylase. This gene is very close to $N p-1$, which controls the mobility of a more widely expressed form of this enzyme.

in this strain was confirmed using isozyme analysis. Using the formulas of Taylor (1981), the recombinant inbred strain mapping results give the following order and distances (in centiMorgans): Rib-1-(4.72 \pm 2.50 )$R b-1-(0.77 \pm 0.79)-E s-10$. The $95 \%$ confidence limits (Silver, 1985; Silver and Buckler, 1986) for these recombination distances are Rib-1-(1.34-14.54)-Rb-1$(0.02-4.98)-E s-10$. Note that the exceptional strain has previously been classified as being recombinant between Es-10 and the next most proximal marker, Rib1 . The most likely gene order, centromere-Rib-1-Rb$1-E s-10$ is greater than 8.5 times more likely than the next most likely gene order, centromere-Rib-1-Es-10$R b-1$, as evaluated by lod score analysis (not shown).

\section{Linkage of $R b-1$ to $h r$}

The relationship between $R b-1$ and the hairless mutation, $h r$, was investigated because this mutation might serve as a useful visible marker in further studies of $R b-1$ and because the HRS/J strain is characterized by a relatively high incidence of lymphomas and papillomas. The hairless mutation has been localized to the vicinity of $E s-10$, based on the following observation. The HRS/J inbred strain of mice is maintained by mating $+/ h r$ females to $h r / h r$ sibling males. At the 60 th generation of inbreeding it was observed that +1 $h r$ females were of genotype Es-10 $/ E s-10^{b}$ while homozygous $h r / h r$ males were homozygous for $E s-10^{b} /$ $E s-10^{b}$, although no selection for $E s-10$ type had been exercised (Cummings et al., 1979). Since the mean length of the heterozygous segment in such a strain is expected to be about $1.25 \mathrm{cM}$ at the 60 th generation, it was concluded that the two genes are very close.

We typed HRS/J animals that were at the 81st generation of inbreeding for $E s-10$ and for $R b-1$. Heterozygous $+/ h r$ females were found to be heterozygous $R b-1^{b} / R b-I^{d}$ as well as heterozygous for $E s-10^{a}$ and $E s$ $10^{b}$. Males homozygous for $h r$ were shown to be homozygous for $E s-10^{b}$ and $R b-1^{d}$ (Table 4).

A variant strain HRS/J, referred to here as HRS/ $\mathrm{J}^{*}$, was discovered at The Jackson Laboratory during routine quality control isozyme typing, at the 70th generation of inbreeding. This strain is homozygous

\section{TABLE 4}

Distribution of $R b-1$ Alleles in $h r$ Strains

\begin{tabular}{|c|c|c|c|c|c|}
\hline \multirow[b]{2}{*}{ Strain } & \multirow[b]{2}{*}{ Sex } & \multirow[b]{2}{*}{ No. } & \multicolumn{3}{|c|}{ Genotype } \\
\hline & & & $h r^{a}$ & $R b-1$ & Es-10 \\
\hline \multirow[t]{2}{*}{ HRS/J } & F & 2 & $h r /+$ & $d / b$ & $a / b$ \\
\hline & $\mathbf{M}$ & 2 & $h r / h r$ & $d / d$ & $b / b$ \\
\hline \multirow[t]{2}{*}{$\mathrm{HRS} / \mathrm{J}^{a}$} & $\mathbf{F}$ & 1 & $h r /+$ & $d / b$ & $b / b$ \\
\hline & $\mathbf{M}$ & 1 & $h r / h r$ & $d / d$ & $\mathrm{~b} / \mathrm{b}$ \\
\hline \multirow[t]{2}{*}{ WLHR } & $\mathbf{F}$ & 1 & $h r / t$ & $\mathrm{~b} / \mathrm{b}$ & c/c \\
\hline & $\mathbf{M}$ & 1 & $h r /+$ & $b / b$ & $\mathrm{c} / \mathrm{c}$ \\
\hline
\end{tabular}

Note. Genotype symbols are described in the text.

${ }^{a}$ Heterozygosity at $h r$ was confirmed by progeny testing. 
for $E s-10^{b}$, even in $+/ h r$ animals. We found that the $+/ h r$ animals, however, are heterozygous for $R b-1^{b} / R b$ $1^{d}$. Thus, a crossover event between $h r$ and $E s-10$ occurred but this event was not in the $h r-R b-1$ interval.

Another strain carrying the $h r$ mutation also proved informative. The WLHR strain is a "balanced lethal" stock that is maintained by mating $+w l / h r+$ siblings; the virtually lethal $w l$ (wabbler-lethal) mutation is maintained by mating heterozygotes, with the closely linked $h r$ serving as a visible marker that facilitates the identification of suitable breeding pairs. The WLHR strain is homozygous for the rare $E s-10^{c}$ allele (Poland et al., 1984). Two animals from the WLHR strain were typed and found to be homozygous for $R b$ $1^{b}$ (Table 4). Although the origin of this stock is somewhat obscure, it seems likely that a crossover event has placed an $E s-10^{c}$ allele as well as the $R b-1^{b}$ allele in cis with $h r$.

\section{DISCUSSION}

We predicted close linkage of $R b-1$ to $E s-10$ on mouse chromosome 14 based on the likelihood that the latter is the murine homolog of ESD and on the substantial documentation that linkage relationships have been widely conserved in mammalian evolution (Nadeau and Reiner, 1989). The products of Es-10 and ESD are cytosolic, dimeric enzymes that utilize 4-methylumbelliferal acetate but not naphthyl esters as substrates. Both the human and the mouse genes are expressed ubiquitously. In humans, $E S D$ and $R B I$ are closely linked; they are co-deleted in some cases of familial retinoblastoma (Sparkes et al., 1980). The data presented here clearly demonstrate close linkage of $R b-1$ to $E s-10$ on mouse chromosome 14. Given the observation that the murine homolog of $E S D$ also is tightly linked to $R b-1$, the data support the hypothesis that $E s d$ and $E s-10$ are the same. It should be noted, however, that the data do not rule out the possibility of more than one esterase-encoding gene in this region. This possibility is highlighted by the fact that at least seven loci controlling esterase isozyme patterns have been mapped to the median segment of chromosome 8.

Close linkage of $R b-1$ and $h r$ is also implied by the maintenance of heterozygosity of both in the HRS/J strain for over 60 generations of inbreeding, as well as by the well-documented tight linkage of Es-10 and $h r$. When all of the linkage data are taken into account, it seems likely that $h r, R b-1$, and $E s-10(E s d)$ are within a centiMorgan or so, corresponding to a physical segment of about $2000 \mathrm{kbp}$. Three recombination events in this small interval have been documented here. If it is assumed that each recombinant chromosome represents a single crossover event, then the gene order must be centromere- $h r-R b-1-E s-10$. Furthermore, in the two cases involving $h r$, where all three genes can be typed, one involved a crossover distal and one occurred proximal to $R b-1$. Thus, $h r$ would appear to be as close genetically to $R b-1$ as $E s-10$, given this very limited number of observations. These mapping results are depicted in Fig. 2. Using radiation-induced chromosome breakage techniques in somatic cells, $E s-10$ has been assigned to chromosome 14 bands D2-E2 (Samuelson and Farber, 1985). The localization of $R b$ 1 to this region may help in the interpretation of possible karyotypic anomalies in murine neoplasia.

The role of $R b-1$ in murine tumors is unknown. Proteins closely related to the human and murine retinoblastoma products co-precipitate with E1A antigen and large $\mathrm{T}$ antigen from adenovirus-transformed and SV40-transformed mammalian cells, respectively, suggesting that this cellular gene may play a central role in the control of cell proliferation in mammals (Whyte et al., 1988; Decaprio et al., 1988). Consistent with this notion, $R b-1$ is expressed in a wide variety of mouse tissues and the gene is conserved in vertebrate evolution (Bernards et al., 1989). The dichotomy between the wide distribution of normal tissue expression and the narrow spectrum of human cancer types associated with $R b-1$ alterations, however, raises an interesting enigma concerning the normal function of the retinoblastoma gene versus the pathophysiologic consequences of its loss. Perhaps loss of function of the retinoblastoma gene is lethal in most cell types while it leads to tumors in exceptional settings. Alternatively, perhaps most cells express other genes that perform the same function, making the tumor-suppressing function of $R B 1$ redundant in all but retinoblasts and certain connective tissues. It is also not clear to what extent the function of the retinoblastoma gene is conserved between species. Retinoblastoma has not been reported in species other than humans. Certainly an experimental animal system for the analysis of the gene would be invaluable.

Taking advantage of the discovery that the $h r \mathrm{mu}$ tation is associated with an endogenous polytrophic virus insertion, DNA probes from the $h r$ locus have recently been isolated (Stoye et al., 1988). Es-10 and $h r$ variants, therefore, may serve as useful genetic tools for monitoring $R b-1$ in somatic and germline genetic

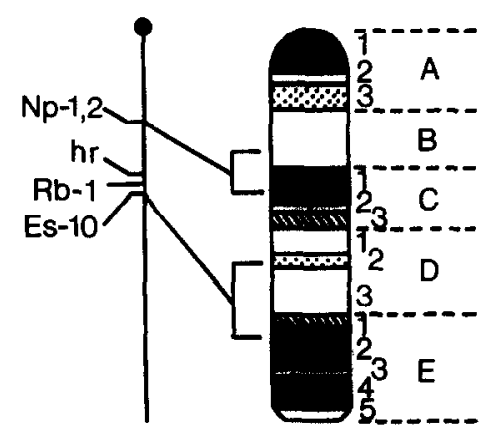

FIG. 2. Summary of mapping results. 
experiments. It may even be possible to exploit these markers to recover germline deletions of $R b-1$.

\section{ACKNOWLEDGMENTS}

This work was supported by NIH Grant CA44900 to J.C.S. and GM39414 to J.H.N. The authors thank Don Varnum, Carolyn Dunbar, and Kathy McGraw for their expert technical assistance, Dr. Eva Eicher and Linda Washburn for the $M$. spretus, and Dr. Jeremy Squire and Dr. Brenda Gallie for the ESD probe.

\section{REFERENCES}

1. Bernards, R., Shackleford, G. M., Gerber, M. R., HoroWITZ, J. M., FRIEND, S. H., SCharTl, M., BogenManN, E., DRYJA, T. P., AND WeInBERG, R. A. (1989). Structure and expression of the murine retinoblastoma gene and encoded protein. Proc. Natl. Acad. Sci. USA, in press.

2. Cavenee, W. K., Dryja, T. P., Phillips, R. A., Benedict, W. F., GodBout, R., Gallie, B. L., MURPHREe, A. L., STRONG, L., AND WHITE, R. L. (1983). Expression of recessive alleles by chromosomal mechanisms in retinoblastomas. Nature (London) 305: 779-784.

3. Cummings, R. B., Walton, M. F., Fuscoe, J. C., Taylor, B. A., WOMACK, J. E., AND GaERTNER, F. H. (1979). Genetics of formamidase-5 (brain formamidase) in the mouse: Localization of the structural gene on chromosome 14. Biochem. Genet. 17: 415-431.

4. DECaPRio, J. A., Ludlow, J. W., FigGe, J., ShEW, J.-Y., HuANG, C.-M., LeE, W.-H., MARSILIo, E., PAUCha, E., AND LivingSTON, D. M. (1988). SV40 large tumor antigen forms a specific complex with the product of the retinoblastoma susceptibility gene. Cell 54: 275-283.

5. DEMRIC, Z., BANNWORTH, W., TAYLOR, B. A., AND STEINMETZ, M. (1985). The gene encoding the T-cell receptor alpha-chain maps close to the $\mathrm{Np}-2$ locus on mouse chromosome 14. Nature (London) 314: 271-273.

6. DunN, J. M., PHILlips, R. A., BeCKeR, A. J., AND GALlie, B. L. (1988). Identification of germline and somatic mutations affecting the retinoblastoma gene. Science 241: 1797-1800.

7. Elliot, R. W., SAMuelson, L. C., LAMBerT, M. S., AND MeiS LER, M. H. (1986). Assignment of the pancreatic ribonuclease gene to mouse chromosome 14. Cytogenet. Cell Genet. 42: 110112.

8. FeinberG, A. P., AND Vogelstein, B. (1983). A technique for radiolabeling DNA restriction endonuclease fragments to high specific activity. Anal. Biochem. 132: 6-13.

9. Friend, S. H., Bernards, R., RogeLJ, S., Weinberg, R. A., RAPAPOR', J. M., ALBERT, D. M., AND DRYJA, T. P. (1986). Identification of a human DNA segment having properties of the gene that predisposes to retinoblastoma and osteosarcoma. Nature (London) 323: 643-646.

10. Friend, S. H., Horowitz, J. M., Gerber, M. R., WanG, X.-F., BogenMaNN, E., Li, F. P., AND WEINBERG, R. A. (1987). Deletions of a DNA sequence in retinoblastomas and mesenchymal tumors: Organization of the sequence and its encoded protein. Proc. Natl. Acad. Sci. USA 84: 9059-9063.

11. Fung, Y.-K. T., MURPhreE, A. L., T'ANG, A., QIAN, J., HiNRICHS, S. H., AND BENEDICT, W. F. (1987). Structural evidence for the authenticity of the human retinoblastoma gene. Science 236: $1657-1661$.

12. Goddard, A. D., Balakier, H. C., Canton, M., DunN, J., SQuire, J., ReYes, E., BeCKER, A., PHILliPS, R., AND GALLIE, B. L. (1988). Infrequent genomic rearrangement and normal expression of the putative RB1 gene in retinoblastoma tumors. Mol. Cell. Biol. 8: 2082-2088.
13. HogGaN, M. D., HALdEN, N. F., BUCHLER, C. E., AND KozAK, C. A. (1988). Genetic mapping of the mouse c-fms proto-oncogene to chromosome 18. J. Virol. 62: 1055-1056.

14. KLEIN, G. (1987). The approaching era of the tumor suppressor genes. Science 238: 1539-1545.

15. KNUDSON, A. G. (1971). Mutation and cancer: Statistical study of retinoblastoma. Proc. Natl. Acad. Sci. USA 68: 820-823.

16. LeE, W.-H., Bookstein, R., Hong, F., Young, L. J., SHew, J.-Y., AND LEE, E. Y.-H. P. (1987a). Human retinoblastoma susceptibility gene: Cloning identification and sequence. Science 235: 1394-1399.

17. Lef, W.-H., SheW, J.-Y., HoNG, F. D., SERY, T. W., Donoso, L. A., Young, L.-J., Bookstein, R., AND LeE, E. Y.-H. P. (1987b). The retinoblastoma susceptibility gene encodes a nuclear phosphoprotein associated with DNA binding activity. Nature (London) 329: 642-645.

18. NADEAU, J. H., AND REINER, A. H. (1989). Linkage and synteny homologies between mouse and man. In "Genetic Variants and Strains of the Laboratory Mouse" (M. F. Lyon and A. G. Searle, Eds.), Oxford University Press, in press.

19. Poland, A., KNUTSON, J. C., AND Glover, E. (1984). Histologic changes produced by 2,3,7,8-tetrachlorodibenzo-p-dioxin in the skin of mice carrying mutations that affect the integument. $J$. Invest. Dermatol. 83(6): 454-459.

20. Samuelson, L. C., AND FARBER, R. A. (1985). Cytological localization of adenosive kinase, nucleoside phosphorylase- 1 and esterase-10 on mouse chromosome 14. Somat. Cell Mol. Genet. 11: $157-165$.

21. SILVER, J. (1985). Confidence limits for estimates of gene linkage based on analysis of recombinant inbred strains. J. Hered. 76: 436-440.

22. SILVER, J., AND BUCKLER, C, E. (1986). Statistical considerations for analysis using recombinant inbred strains and backcrosses. Proc. Natl. Acad. Sci. USA 83: 1423-1427.

23. Sparkes, R. S., MURPhREe, A. L., LingUa, R. W., SParkes, M. C., FIELD, L. L., FunderbuRK, S. J., AND BENEDICT, W. F. (1983). Gene for hereditary retinoblastoma assigned to human chromosome 13 by linkage to esterase D. Science 219: 971 973.

24. Sparkes, R. S., Sparkes, M. C., Wilson, M. G., Towner, J. W., BENEDICT, W., MURPHREE, A. L., AND YUNIS, J. L. (1980). Regional assignment of genes for human esterase $D$ and retinoblastoma to chromosome band 13q14. Science 208: 10421044.

25. Squire, J., Dryja, T. P., Dunn J., Goddard, T., Hofmann, M., Musarella, M., Willard, H. F., Becker, A. J., Gallie, B. L., AND PHILliPS, R. A. (1986). Cloning of the esterase D gene: A polymorphic gene probe closely linked to the retinoblastoma locus on chromosome 13. Proc. Natl. Acad. Sci. USA 83: 6573-6577.

26. Stoye, J. P., Fenner, S., GreenoAK, G. E., Moron, C., AND CofFin, J. M. (1988). Role of endogenous retroviruses as mutagens: The hairless mutation of mice. Cell 54: 383-391.

27. TAYLOR, B. A. (1981). Recombinant inbred strains: Use in gene mapping. In "Origins of Inbred Mice" (H. C. Morse, III, Ed.), pp. 423-438, Academic Press, New York.

28. Whyte, P., Buchkovich, K. J., Horowitz, J. M., Friend, S. H., RAYBUCK, M., WeINBERG, R. A., AND HaRLOW, E. (1988). Association between an oncogene and an anti-oncogene: The adenovirus E1A proteins bind to the retinoblastoma gene product. Nature (London) 334: 124-129.

29. WomaCK, J. E., Davisson, M. T., EICHER, E. M., AND KENDALL, D. A. (1977). Mapping of nucleoside phosphorylase $(N p-1)$ and esterase-10 $\left(E_{s-10}\right)$ on mouse chromosome 14 . Biochem. Genet. 15: $347-355$. 